\title{
The power and difficulty of one-page articles
}

\author{
Minh-Hoang Nguyen \\ Centre for Interdisciplinary Social Research \\ Phenikaa University \\ Yen Nghia, Ha Dong, Hanoi 100803, Vietnam
}

October 3, 2021

$* * * * *$

My mentor has written many works, including many advanced conceptual papers [1-4] and even a 550-page book with the current Vietnamese Prime Minister [5]. Still, he told me that the most valuable publications are probably his one-page articles [6-8].

But, how an article with a very strict word limit could have even more impact than a 550-page book packed with ideas, data and figures, has still been a myth for me?

It is worth knowing that all those three articles were published in the World View columns of Nature and Nature Human Behaviour, two of the most precious scientific journals in the world. Articles published here are considered the global perspectives by Nature and Nature Human Behaviour and are expected to create impacts on the international scale and somehow shape the thoughts among international scientific communities. Until now, only 582 articles have been published in the World View column of the 150-year-old Nature. Despite immense impacts, any articles published in this column must not exceed 1,000 words, or equivalent to one page.

The power of a one-page article lies in its limited word number. The main function of a World View article is to convey the author's ideology on a specific matter, which can potentially influence, inspire, and even be a "lighthouse" for other scholars. By keeping the paper's length short, readers can absorb the information more quickly and remember them for a longer time, facilitating the circulation of ideologies.

Writing a one-page ideological paper similar to any of my mentor's masterpieces must meet two mandatory requirements. First, the content conveyed in the paper has to be holistic and inclusive to make sure it can be interpreted beyond the boundary of time and place. Moreover, being constrained by the word limit, the language used must be concise, and the evidence given must be representative. Without achieving any of these criteria, the one-page article will become either overclaimed or lack persuasion. 
Because of these harsh requirements, having a one-page article with a global impact is extremely difficult. Even my mentor had to admit, "it is hard to know when I can write the next one-page article. Perhaps, there might be no chance."

I completely agree with him on the slim chance of getting those one-page articles done. Writing this short paper can exemplify that difficulty. While I do not have to pack the short pieces with crucial ideas, optimize the flow of facts, or face constraints on "just writing what really matters", completing the paper within one page is still a tremendous challenge. Most of the time, I started with a clear head and ended up drowning in a mess of disconnected ideas, totaling up to several pages.

That has led me to a "personalized problem": When will I be able to nail such a one-page high-impact manuscript?

\section{References}

1. Vuong QH. (2021). The semiconducting principle of monetary and environmental values exchange. Economics and Business Letter, 10(3), 284-290.

2. Vuong QH et al. (2018). Cultural additivity: behavioural insights from the interaction of Confucianism, Buddhism and Taoism in folktales. Palgrave Communications, 4 , 143.

3. Vuong QH, Nguyen MH, Le TT. (2021). A Mindsponge-Based Investigation into the Psycho-Religious Mechanism Behind Suicide Attacks. Warsaw, Poland: De Gruyter.

4. Vuong QH, Napier NK. (2015). Acculturation and global mindsponge: An emerging market perspective. International Journal of Intercultural Relations, 49, 354-367.

5. Chính PM, Hoàng VQ. (2021). Kinh tế Việt Nam: Thăng trầm và đột phá. Nxb Chính trị Quốc gia, Hà Nội.

6. Vuong QH. (2018). The (ir)rational consideration of the cost of science in transition economies. Nature Human Behaviour, 2, 5.

7. Vuong QH. (2019). Breaking barriers in publishing demands a proactive attitude. Nature Human Behaviour, 3, 1034.

8. Vuong QH. (2020). Reform retractions to make them more transparent. Nature, 582,149 . 